\title{
5 \\ Ruptured Biographies: The Last Yugoslavs
}

All of the Last Yugoslavs were born and grew up in $\mathrm{BiH}$ during socialist Yugoslavia, that is, after WWII. They thus have no personal memories of that war and few, if any, memories of the first years of Tito's Yugoslavia. The youngest of them were in their late teens when the war began in 1992, while the oldest had already established their own households. This generation does not perceive itself as having built up Yugoslavia, as the First Yugoslavs do (who were born before WWII and were in their adolescence and early adulthood in the first period of Tito's Yugoslavia), but rather as its beneficiaries.

This chapter shows how the Last Yugoslavs, a generation that finds itself between old and new politico-ideological outlooks, deals with the discrepancies they are confronted with when positioning themselves towards the past. The war in the 1990s led to a rupture in terms of a discontinuity in public discourse. It also constituted a period of rupture in the lives of the people. The war was experienced as a disruption in the biographies of all the people I talked to, but the narratives of this generation with their specific discursive tactics show the rupture most prominently.

The Last Yugoslav generation is the generation that grew up under relatively stable political circumstances. At the time the war started, the Last

(C) The Editor(s) (if applicable) and The Author(s) 2016 
Yugoslavs either already had their own households and were pursuing their careers or were just about to do so. The particular life situation the Last Yugoslavs found themselves in when war broke out and still find themselves in at the point of narrating the past is crucial in understanding the Last Yugoslavs' narratives of the war and the effect it had on their lives.

A central discursive tactic characteristic of this generation is the switching between opposing discourses, one vividly and positively remembering life in Yugoslavia and one defending the national developments that resulted in the division of Mostar. The switching between opposing discourses will be discussed in particular concerning Minela and Željko later in this chapter. Both sought explanation for these discrepancies in the fact that they and their nations were suppressed during socialist Yugoslavia, but that they were not aware of it at the time. In this way, they devalued their own autobiographical memories (see Volcic 2007).

As outlined in the Introduction to this book, studies on memory and Yugoslavia (and its successor states) have primarily concerned themselves with collective, national memory (see, e.g., Basic-Hrvatin 1996; Dujizings 2007; Hayden 1994; Moll 2013; Müller 2002). The far fewer studies that have focused on personal memories or the intersection of personal and national memory primarily dealt with memories (collective as well as personal) of violence and war. The impact of the enormous political-economic transformations in the way in which people reflect on the past has received little attention. This chapter shows, however, that these transformations play key roles in understanding life narratives, particularly those of the generation in question here. The immediate time of the political-economic crisis is experienced and thus set in relation to past time (memory) and future time (prospects).

Regardless of whether people remained in Mostar throughout the entire period of the war or fled to (more) secure places and only returned after the war had ended, they were forced to build a new life in a place that had seen severe transformations. Facing great obstacles and insecurities, many were left in doubt about whether it was the right decision to return to (or remain in) Mostar. While the war and the far-reaching transformations that accompanied it were decisive for everyone, the 
Last Yugoslavs experienced the war most prominently as a rupture in their lives. Constituting a relatively big cohort, the Last Yugoslavs have spent most of their lives in Yugoslavia and grew up under relatively stable political and economic circumstances, in contrast to the First Yugoslavs and the Post-Yugoslavs, who spent part of their childhood or early adulthood either during WWII or during the 1992-1995 war. In contrast to the First Yugoslavs, who had already experienced a war and who knew that war always comes unexpectedly, the Last Yugoslavs simply could not imagine a war in Yugoslavia.

The Last Yugoslavs find themselves at a stage of their lives in which they have to, in some way or other, face the political, economic and societal changes they are confronted with. Compared to the Last Yugoslavs, the First Yugoslavs have reached an age that allows them more freedom to retreat into the past and delve into memories of better times with others of a similar age (see Palmberger 2008). Those belonging to the Post-Yugoslav generation, on the other hand, have spent most of their lives in post-war Mostar and do not experience the war as such a prominent rupture in their lives in the way the Last Yugoslavs do. The loss of social security and economic well-being (compared to the present extremely precarious economic situation) has had a severe impact on the lives of the Last Yugoslav generation, as they carry great economic responsibility today, not only for themselves but also for their children and often for their parents. Moreover, the education of many of this generation was delayed due to the war, and the career prospects they held (or retrospectively believe they held) during socialist Yugoslavia vanished.

The transformation of the Yugoslav socialist market economy into a neoliberal, capitalist-oriented economy (see Pugh 2005; see also Hann et al. 2002) directly and most severely affected the lives of the Last Yugoslavs. In this respect, Jansen (2008: 47), working with returnees in $\mathrm{BiH}$, describes the generation who are (or are supposed to be) in the middle of their working lives as particularly vulnerable and thus reluctant to return to their hometown on a permanent basis. Even if future prospects for the younger generation, the Post-Yugoslavs, are similarly grim, they do not feel robbed of their hopes and prospects in the same way as the Last Yugoslavs because they grew up during a time already marked by extreme insecurity. 
The economic downfall experienced by Mostarians was stark: ten years after the Dayton Peace Agreement was signed in 1995, gross domestic product (GDP) per capita in $\mathrm{BiH}$ was still less than $50 \%$ of its pre-war level. The average income in $\mathrm{BiH}$ is around 400 Euros a month and about $40 \%$ of the population describes their household situation as below average (see UNDP 2008). Some of the Last Yugoslavs even told me that it was easier during the war, because back then people 'only' had to care about their basic existence and not about electricity bills and so on.

For the generation of the Last Yugoslavs, one of the greatest (if not the greatest) concerns is Mostar's extremely weak job market. Many of the public enterprises went bankrupt due to the war, the loss of markets and a dislocated labour force. As Pugh (2005) reveals, bankruptcy was also an effective way for realizing the privatization promoted by the so-called international community active in $\mathrm{BiH}$ after the war. The privatization of public enterprises was propagated as the key to economic growth in $\mathrm{BiH}$. In many cases, however, the enterprises fell into the hands of corrupt nationalist managers and did not contribute to improving the economic situation of Mostar's larger population. Interestingly, most people saw the economic downfall in connection to the war rather than to neoliberal post-war policies. Thus, the experience of the war and the disappearance of socio-economic security were narrated as one disruption that separated their lives into a life before and a life after.

After the war, shadow markets became an important survival mechanism used by many inhabitants to stop themselves from falling below the poverty line (Pugh 2005: 451-456; see also Papić 2001), as illustrated by the example of Igor, a Croat in his late 40s. When fighting for the Croat army, Igor was injured twice and now receives an invalid's pension, but the amount he receives is far too small to support his family. For this reason Igor, a trained electrical engineer, has to work on the side as a pool attendant. Igor is very pessimistic about Mostar's future:

Life is difficult here. I believe people fight for their bare existence. One cannot see any improvement. What can I, for example, provide for my children? But it is not only difficult for me but also for them; what can they do here, which profession should they assume? There are no jobs; there is no future whatsoever! You cannot see any! 
Even if the situation of the war invalids presents a special case, Igor's disappointment with his current situation and his pessimism for the future is shared by many of the Last Yugoslavs, both men and women. Employment is a central concern for this generation.

Aner, one of my Bosniak informants, who was one of the youngest soldiers in the Army of $\mathrm{BiH}$ during the war in the 1990s (and who was in his early 30s when I met him), is convinced that traumatic war experiences are not as threatening as the economic insecurity people face. Even though he told me quite openly about the depression he suffers, he hesitated to connect his symptoms with personal war experiences. Instead, he linked them first and foremost to his desperate economic situation and his hopeless career opportunities. Aner believes that post-traumatic stress disorder (PTSD) is only a myth ${ }^{1}$ that has been exploited for political reasons and is convinced that people in post-war $\mathrm{BiH}$ are primarily concerned with practical issues like finding a job. At the time I got to know Aner, he worked in a small private-run grocery shop, but he knew that the shop would be closed in the near future, since it was no longer profitable.

For Aner, the war and the break-up of Yugoslavia constitute a clear disruption to his life, which is characteristic of the narratives of the Last Yugoslavs. Their narratives are clearly divided into a three-fold time frame: before the war, during the war and after the war. To give only one example, after Aner had given me a comprehensive account of his experiences as a soldier, he told me that he had played the piano before the war. There are two remarkable observations about this statement. First, the time reference is the war, not a year or date or his age at the particular time. Second, the statement 'before the war I played piano' is a statement that not only informs the interlocutor about musical skills, but also aims to capture the approach to life that people held in pre-war Mostar. Aner told me about his past as a piano player right after he had told me about his life as a soldier. Making music and shooting people represent polar opposite activities. The former stands for a truly 'peaceful' activity; the latter stands for the opposite, absolute violence. The statement 'before the war I played piano' in the context of his narration also expresses that, at that point in his life, Aner had never imagined that he would ever hold

${ }^{1}$ For a critical discussion of PTSD diagnosis see Young (1995). 
a rifle in his hand. Moreover, it implies that since this point, nothing has remained the same.

The war severely changed the life course of those who fought as soldiers and also of civilians who blamed the war for delaying or hindering their education/career and/or their aspirations to start their own family. The war narratives of those who experienced the war as civilians (among the Last Yugoslavs, these were mostly women) often centred on their families. Those who already had children of their own when the war broke out mourned for the time with their children that they lost due to the war. In extreme cases, parents were separated from their children when they were moved to safer locations. One mother who shared this fate broke into tears when she told me her story. While she and her husband remained in $\mathrm{BiH}$ throughout the war, their two children lived in Germany. Even when her children assure her that she made the right decision, she still grieves over the long period of separation.

In order to carve out the above-presented particularities of the Last Yugoslav generation, in a next step I will analyse the narratives of some of my interlocutors in more detail.

\section{Aida: A Lost Home}

I was introduced to Aida by one of her lecturers at the university on Mostar's east side. Back in 2006 Aida was in her final year of English studies. She already held a degree in science but decided to do a second degree in English - the language she had become familiar with as a refugee in Great Britain during the war-hoping to increase her chances in Mostar's weak job market. In her late 30s at the time, she was older than most of her fellow students who were still in their early and mid-20s. Aida was not alone in having a delayed education or career path; due to the war, many of the Last Yugoslavs shared this fate.

Aida, who was at the end of her science study when the war began, had pictured her future life in a very different way than how it eventually evolved. She experienced the war as an unexpected event that foiled her life prospects. Her narrative has a strong component of nostalgia for her pre-war life. She divides her life into three clear-cut periods: life before 
the war, during the war and after the war. According to Tannock (1995) this thrice-divided time frame characterises nostalgic narratives. The rhetoric of nostalgia is always centred around a lapse that was preceded by the pre-lapsarian world - where everything was good or at least substantially better - and is succeeded by a post-lapsarian world where everything has become worse (Tannock 1995: 456). Pre-war BiH is presented as the 'secure past', while present and future $\mathrm{BiH}$ are seen as insecure (in some cases even for those who are in favour of Mostar's division, as will be shown in the proceeding text). The act of comparison is imminent in nostalgia since it always forms a reaction to the present state (Davis 1977: 417). This makes clear that nostalgic feelings are never directed towards the past alone but always tell us something about the perception of the present as well as the dreams and fears of the future (Boym 2001; Davis 1979; Pickering and Keightley 2006; Radstone 2010;). ${ }^{2}$

There are two central events in Aida's narration of the war: the imprisoning of her father and brother, and the parting from her parents. At the beginning of the war between Croats and Bosniaks in 1993, her father and brother were taken to a detention camp. Fortunately they were freed after a few days, but Aida describes those days of waiting as a nightmare for her and her mother. Neither of them could sleep; they were restless and worried about the lives of the two men. When Aida told me about those days, her descriptions were so detailed that it was almost as if she were re-living the past once more. When the men were finally released, Aida and her brother fled the country. This moment of leaving Mostar is central in Aida's narrative of the war. Although her parents had insisted their children should leave the country, it was the first time Aida saw her parents cry, which made her realise they might never see each other again.

In the first months Aida spent away from Mostar, in a refugee camp in Croatia, she felt stripped of any privacy and autonomy. Many of my interlocutors narrated the time they spent as refugees in similar ways; the loss of privacy and autonomy is central in their accounts. In his seminal work, The Politics of Storytelling, Jackson (2006) describes this experience

\footnotetext{
${ }^{2}$ In Ugrešićs (2006) well-written novel The Ministry of Pain, we learn about the gravity Yugonostalgia can bear for Aida's generation.
} 
of losing subjectivity as a decisive experience for refugees and as a form of violation of a person's humanity.

For Aida, this state of her life only changed when she arrived at her host family's home in Great Britain. There she found a new-albeit temporary-home. While she was in Great Britain, Aida's mother was expelled from the west side to the east side of Mostar in 1994 while her father was kept in a detention camp once again. Since their expulsion, Aida's family has been living on the east side of Mostar, and after the war they sold their former flat in West Mostar. In 1997 Aida had to return to $\mathrm{BiH}$ at a time when she had already established herself both personally and professionally in Great Britain. Upon her return, she hardly recognised her hometown; not only did its physical shape show heavy damage but the social order had been destroyed as well. The city was divided and most of her friends had left the city. In order to explore her experience of loss of home, which started with the outbreak of the war and did not end with the ceasefire or with Aida's return to Mostar, we need to further investigate her position vis-à-vis Yugoslavia as well as her present life situation.

Aida describes herself as Muslimanka (Muslim), although not a practising one. She never joins in prayers at the mosque and tells me that, frankly, she has never learned how to pray. In her family, values taught by Tito such as Brotherhood and Unity had always outweighed any religion, she reminds me on several occasions. Still, the members of her family perceive themselves as Muslimani (as a national distinction from Croats and Serbs more than in a religious sense) and celebrate the most important religious holidays. With the war and Mostar's division, her Muslim/Bosniak identity became part of everyday life. Aida studies at the Bosniak-dominated university and teaches in an east-side school which follows the Bosniak curriculum. Her close friends are all Bosniaks and when they meet they do so in cafés in East Mostar.

Aida grew up with her maternal grandmother (who was divorced from Aida's grandfather), a non-practising Muslim. Her grandmother's second husband, Aida informs me, was a Serb or actually a Partisan, a communist, as she immediately corrects herself. Her maternal grandfather (her grandmother's first husband) was also a Partisan. He had reached a high rank in the Partisan army during WWII and was therefore well respected after the war ended. Aida mentions that her grandfather's second wife 
was a Serb, as if to stress the fact that her family was a true communist family to whom nationality did not matter. From her grandfather Aida had learned a lot about the history of the Partisan movement, and I was impressed by how she was able to recall a great number of facts about Partisan battles and former Yugoslav holidays. In 1985, at the age of 17, Aida became a member of the League of Communists of Yugoslavia (Savez komunista Jugoslavije) but burned her membership card in 1993 because she feared it would be held against her if discovered.

Although Aida was open about the fact that she regrets that Tito's Yugoslavia is gone, there was still a kind of secretive atmosphere whenever she talked about it. One day, she said to me in a hushed voice, as if sharing an intimate detail of her life: 'I have to tell you, I am a Yugo-nostalgist!' This 'confession' was followed by praise for the low unemployment rate under Tito, the health insurance everyone enjoyed, the good income as well as the free education. 'And nobody asked you about your religion, everyone got along well. Mostar was the place with the highest number of inter-ethnic marriages', she added. Aida does not acknowledge any comparison of Yugoslavia with other socialist countries and was very disappointed especially when foreigners made such comparisons. In order to address any possible doubts on my side, Aida told me:

Before the war I went out every night. It was a common practice for parents to give their children money to go out every day. My parents for example were both working and had a good income which we could live a carefree life. I could go out and eat out every night with my friends if I wanted. And not only this, we could also spend a whole month on the coast each summer. Families got a cheap place from the employer for their holidays.

Aida closed her defence of Yugoslavia by saying: 'If I had a hero it would be Tito. This man is my hero! I have to tell you I am really not confident in what the future will bring us' (Fig. 5.1).

Aida believes that the future looked more promising after World War II than after the 1990s war. As her grandmother who raised her used to tell her, a powerful reconstruction of destroyed Yugoslavia was under 


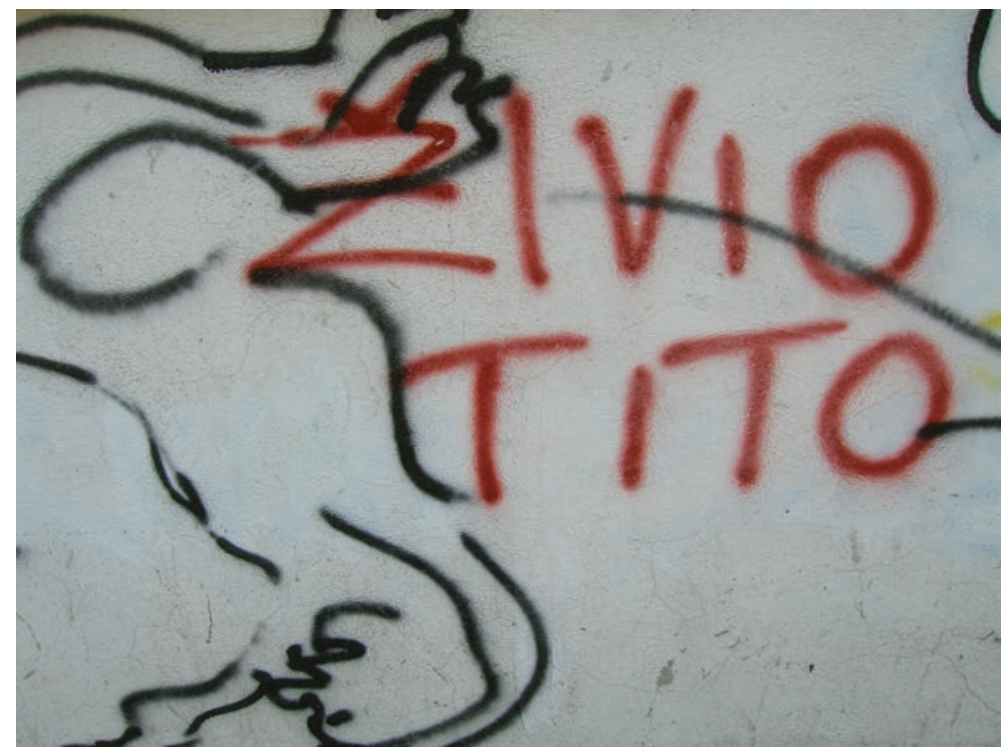

Fig. 5.1 Graffito stating: 'Živio Tito' ('Long live Tito'). Photo by the author

way soon after WWII. Young people at the time responded to the call to volunteer in several big national reconstruction projects. Aida told me:

That was the reconstruction movement (radne akcije). Everyone was optimistic that the situation would improve and they all backed Yugoslavia. These people were volunteering because they believed in it. Many things were built this way, for example railway lines, big factories and such things. This was Yugoslavia at the start. After WWII, from the mid 1950s onward, everything got better. The country rebuilt itself and progressed. Out of its own strength it recovered and got better each day indeed. The standard of living became higher and higher, apartments were built, plenty of jobs were available, good schools and higher education were free for everyone. My grandmother always said that life was best in the 1970s. The state was strong, salaries were good, and one could enjoy the good pension system, health insurance, long vacations, free education. It was indeed great! Midway through the 1980s it started to get worse.

Aida was constantly reminded by her grandparents (just as the youngest generation, the Post-Yugoslavs, today are reminded by those who fought 
in the war of the 1990s) of the struggles their generation went through in order to secure the life she later enjoyed. As Aida's case shows, grandparents, not least because they often took over an important part in raising their grandchildren, were crucial in the transmission of memories to the Last Yugoslavs generation (see Bertaux and Thompson 2009). Aida felt as if she were reaping the benefits of the work of her grandparents' generation and of Tito, and that she owed them all her gratitude. This also became clear whenever Aida defended Tito. Several times I noticed how important it was for her that the 'world' (i.e., 'the West') knew what Yugoslavia really was like. Tito was no dictator, Aida insisted, but provided people with security in healthcare, jobs, education, and so on. It is true that Tito accumulated a lot of luxury, she admitted, but he did not keep it for himself or for his family: 'When he died, the luxury goods became state property again—so we can say he only borrowed it'.

Aida's nostalgia for Yugoslavia is different to that of the First Yugoslavs, described in the previous chapter, since it is first and foremost connected to her personal life and only to a lesser extent to Tito's ideology and the idea of Yugoslavia, a country for all South-Slavs. Her nostalgia mirrors the economic insecurities, the loss of a social network, together with the loss of a life prospect. Besides the changes Mostar went through during the war, Aida was additionally exposed to a different lifestyle and value system in Great Britain which influenced her and further contributed to her sense of alienation.

By the end of my fieldwork, Aida had received her second diploma and left university for good. She had difficulty finding a job as a teacher, and today works only part-time. She is upset at her situation, since her job neither fulfils her nor provides her with the necessary money to leave her parents to establish a household of her own. During Tito's rule, she told me, everyone could find a job: 'You knew that once you completed your education you would find a job and a flat. Life was somehow calmer, not so fast and not so tough. It was much easier and nicer to live back then.'

Aida defends Yugoslavia just as other people may defend their home country. One could say that Yugoslavia is what Aida experiences as home, but a home that no longer exists. Today, Aida gives the impression of being lost in her own 'hometown'-longing for the past and at the same time knowing for sure that this past is gone forever. I am certain that if asked about what her 
ideal future looks like, she would say it would be like Mostar before the war. Aida is aware of the fact that her longing has no chance of being satisfied. Her mourning over the loss (of her home) at times is so overwhelming that she does not feel strong enough to change anything for the better.

While Aida expresses a strong nostalgia for pre-war Mostar, there is little she does to re-enact pre-war Mostar life in her daily practices, for example by making use of the entire city rather than restricting herself to the Bosniak-dominated part of it. Instead, she prefers to remain and to meet with people on the east side. Each time we met, and we met many times in the three years of my stay, she always proposed to do so somewhere on the east side. Only once did we cross sides because I had my children with me and suggested we visit the only proper playground in Mostar, located just across the Bulevar. When we arrived there, Aida immediately called one of her friends and told her that she was in the park for the first time after the war.

Aida's case demonstrates that political loyalties do not necessarily make a difference in the way people move around Mostar and the motivations for not crossing are very diverse. For some it is a matter of insecurity or a lack of trust or even fear, others are restricted by their aim to conform and for yet others it is first and foremost an ideological decision (see Palmberger 2013). In Aida's case I suggest that her reluctance to visit places in West Mostar primarily has to do with the painful experience of loss of her pre-war home (which was located on that side of the city) and only to a lesser degree with conformity and with making a political statement.

\section{Minela and Željko: Shifting Narratives}

\section{Minela}

Minela was one of the first people I met in Mostar. We stayed in very close contact throughout the first half of my fieldwork until she married a Bosnian-German and moved to Germany with him. We became friends although we had opposing views on many social and political issues. I believe it was exactly these differences in opinion that made our conver- 
sations exciting. When I met Minela she was in her late 20s and was looking for a job after she had decided to quit her university studies_-started a couple of years before-due to financial difficulties. She was born on the outskirts of Mostar, where she still lived with her parents when I met her, along with her older brother and her younger sister.

Minela was one of a relatively small group of female interlocutors who stayed in Mostar throughout the entire war. She and her family had stayed in their own house during the whole period of the war. Only her father left to join the Bosniak-dominated Army of $\mathrm{BiH}(\mathrm{ABiH})$ and still today suffers from nightmares about this time in his life. Her little sister was born during the war and Minela felt a special responsibility to look after her when her family had no electricity for two years and experienced food, hygiene and medicine scarcity as well as the terror of shelling. Besides the fear Minela was exposed to, she remembers the war as a time with little privacy and few excitements for a girl in her teens. Her family hosted refugees and the room where people sought shelter was always overcrowded. Conversations were conducted mostly among adults and were of little interest to teenaged Minela. Out of boredom she learned to distinguish the different types of grenades by their sound.

The war was a crucial experience for her and in the many conversations we had it became clear that she perceived this immediate experience of war as a clear break in her biography. Still, it took a long time until Minela would talk about it with me, but I never tried to press her about her experiences and left it up to her whether and, if so, when she would decide to share some of her experiences with me. The first time Minela gave me a detailed account of some of her war experiences came quite unexpectedly and took place when we were sitting together over lunch. The feta cheese I had put in the salad inadvertently triggered Minela's strong memories of wartime because it was often found in the aid packages. I had had similar experiences with other friends on other occasions, who were reminded of the war by, for example, eating lentils or drinking Cedevita, a popular sherbet (see Sutton 2001).

Minela told me that she no longer thinks of the war as much as she used to. Sometimes she realises that she has not thought about it for a couple of weeks. She is relieved by this but at the same time worries about not keeping up her moral responsibility not to forget the crimes committed. 
I was surprised to hear that Minela feared forgetting about what happened during the war since it seemed to be almost always present in her narratives as well as in her daily practices.

Even if Minela did not address the war always explicitly in our conversations, it was present in the structure of her personal accounts. Most of Minela's stories built on personal experiences started with either 'before the war' or 'after the war'. For example, she did not refer to the time before the war as the time when she was a child, but divided her life neatly around the rupture of the war. Her personal age was subordinated to the political developments taking place so that 'before the war' for Minela means 'normal life', 'the good and easy life' and 'Mostar in its true sense'. Another piece of evidence for the presence of the war in her mind, even if not directly addressed in her words, is the way Minela moves around Mostar. She restricts herself to only one part of the city, the one dominated by Bosniaks, and she crosses sides for specific purposes only, such as shopping. She does not feel quite comfortable in West Mostar and always thinks that people can tell that she is a Bosniak.

Although more than a decade has passed, the period after the war (including the present) is still perceived by Minela (similar to Aida) as an abnormal state, a 'state of disorder' and moral decay. Pre-war Mostar for her is the true Mostar, a city she liked and felt at home in. I remember the many hours we spent together which were filled with sentimentally remembering life in Yugoslavia. Her memories referred to Yugoslav rock music, actors, sweets and the Sarajevo Olympic Games held in 1984, as well as memories of solidly multinational neighbourhoods. When I bought the book Leksikon YU Mitologije (Andrić et al. 2004), which is a 'lexicon' of Yugoslavia including celebrities, cultural and sport events, the arts as well as famous politicians of that period, Minela sat on the sofa with me for a couple of hours, flipping through the pages and sharing little anecdotes about many of the entries. Even if she often indulged in nostalgic discourse about Yugoslav times, she would never refer to herself as Yugo-nostalgist, as Aida does. Instead, Minela liked to make fun of Yugo-nostalgists, who she thinks carry a distorted picture of Yugoslavia.

Minela's nostalgia for pre-war Mostar is not connected to the urban-rural discourse encountered in Armen's narrative in Chap. 4. Due to the fact that 
she grew up on the outskirts of Mostar in a village setting, she does not identify herself as an urban Mostarian. It was interesting to hear that for her, not the rural people but the urbanites have spoilt Mostar. Minela finds the way the urban population looks down on rural newcomers unacceptable, especially given the fact that the latter have defended Mostar with their lives and made it possible for the pre-war urban population to return to their hometown. Indeed, she blames those who refer to themselves as pravi Mostarci for the decay of the city as well as of moral values. For her, rural people are much more civilised (kulturniji) than the urbanites. She pointed out that in the villages surrounding Mostar the streets are cleaner, the gardens are better looked after and that generally villagers care to keep their properties tidier. This attitude in Minela is closely connected to a value system that, besides tidiness, includes respect for others, acknowledgement of authority (especially of children towards adults) as well as social responsibility. The decay of this value system she ascribes not only to the urban population but also to a general trend that came with the war or, to be more precise, with the end of the war.

In contrast to Aida, who only mourns her lost home and does not attribute any good qualities to the life that came thereafter, Minela does seealthough on a rather abstract level-positive developments that came with the break-up of Yugoslavia, especially in regard to the awakening of Bosniak national identity. When Minela talks about her Bosniak identity she does so with pride. In contrast to Aida, a central part of being Bosniak for Minela is to be a practising Muslim. ${ }^{3}$ For her and her family, religion became very important during the war and has played a crucial role for them ever since. 'There was only God who could save you', Minela told me. God was important in order to survive this time, she said, and praying gave her family some of the comfort they so needed.

Today, Minela's family fasts during the season of Ramazan and Minela does not show much understanding for those who do not. She does not

\footnotetext{
${ }^{3}$ Minela is member of the Bosniak nationalist party SDA. Her father had taken it into his hands to register his daughter soon after the SDA was founded. Since then Minela always carries her membership card with her in her purse. Although Minela shows respect for the early SDA when Alija Izetbegović was president, she is critical of the current SDA leadership. In the general elections in 2006 she therefore decided to give her vote to SBiH (Stranka za BiH, more liberal and multinational than SDA, although still clearly dominated by Bosniaks).
} 
understand why people call themselves Muslims when during Ramazan they enjoy themselves in Mostar's café and bar scene. Although Minela is quite vehement in her attitude here, she does not endorse the covering of women's hair whatsoever, viewing it as an unnecessary and even repressive gesture. She often emphasises that there was no such tradition in $\mathrm{BiH}$ before the war and that only elderly women in the villages covered their heads back then. She is also very critical of former soldiers from Arabic countries who married Bosnian women in order to remain and settle in BiH. For her, Islam in $\mathrm{BiH}$ is a European Islam that should not be compared with and should not be practised like its counterpart in Arab countries. This view is shared by the majority of Bosniaks I talked to during my fieldwork.

A Bosniak friend of mine, for example, emphasised his support for a liberal and moderate Islam by telling me how happy he was to see that his younger sister went out for drinks with her friends. Although he felt responsible for her, after the early death of both their parents shortly after the war, he said he was more worried about her being introduced to the new group of radical Muslims than about her drinking alcohol. Indeed, the fact that she did not reject alcohol reassured him that she was on the 'right track'. Of course he told me this story with a certain smile on his face; it was common for my informants to stress their acceptance of alcohol in order to prove their moderate Islamic orientation. Despite this liberal attitude, it is also true that religion has increased in importance in $\mathrm{BiH}$ since the break-up of Yugoslavia, for both Christians and Muslims. For many Muslims, as is the case for Minela, Islam has become more central in their lives and religious rules are obeyed more carefully and mosques are visited more regularly than before the war. As described in Chaps. 2 and 3, religion and nation are closely intertwined in $\mathrm{BiH}$.

Importantly, Minela is not only proud of being a Bošnjakinja (Bosniak) or Muslimanka (Muslim) but also of being a Bosanka (Bosnian). In our conversations it became clear that much of her patriotism stems from the experience of war when her compatriots (including her father and other close kin) fought for BiH's independence. This makes it hard sometimes to tell her patriotism for $\mathrm{BiH}$ apart from her national identification as a Bosniak. Minela is aware that soldiers of Croat or Serb background also fought in the $\mathrm{ABiH}$ for an independent and multinational $\mathrm{BiH}$, but she knows the majority were Bosniaks. She does not have much sympathy for 
BiH's Croats and Serbs who do not patriotically stand behind their state but rather stress their national distinctiveness, for example, through language. Only Bosniaks kept their language, Minela once told me: 'I speak like I did before the war. We [Bosniaks] did not change anything. Before the war everyone spoke like this [us].' She added that one did not even know who belonged to which nationality, especially if the name did not tell; and most people did not care, as if they were one big nation. Minela includes herself in the group of people who saw everyone as the same. As if to underline this fact, she said her two best friends before the war were Croat and Serb. This claim for the sameness of the people in Yugoslavia, however, seems to oppose her view of the Bosniak nation as distinct from the Serb and Croat nation.

When referring to pre-wartime, Minela stresses the sameness of people in $\mathrm{BiH}$ and claims that distinctions are artificially created. At other times, however, she follows a discourse that strongly essentialises the Bosniak and Croat identity, thereby emphasising people's differences over their commonalities. This discourse of essentialising identities became most clear when Minela spoke about mixed marriages, especially about children from such marriages. She abruptly stopped arguing that all Bosnians were Bosnians first and foremost but focused instead on their national differences:

Before the war... we were indeed ashamed to say that we were Muslims. Somehow we felt like this. Listen, at the time of Bajram, the last Bajram before the war began, I think it was February, I and a friend of mine were waiting in the hallway for a lecture to begin when someone came in and said, 'Bajram Mubarek Olsun' [Bajram greeting]. We looked like this [she looks with her eyes wide open] because nobody ever said that aloud. Like they were some Hare Krishna or something like that. And so we stayed there and just looked at her like, 'Why do you say that aloud?' as if she was not allowed to say that. It was because of communism. You know, like there is no religion, there is no religion, nothing like that exists, you know? As if it was wrong, you know? That is why we [Bosniaks] often got married to Serbs and Croats and then you lose, you totally lose your identity. You give up your faith for your family; this is why these marriages were not good. You get married and you lose your faith and then you have nothing. Then you just celebrate Christmas and that's it. You call your child, I don't know... Marija, Kristina [Christian names], you know? Or, for example, a woman 
got married to a Serb or I don't know, it does not matter, and then, for example, immediately gave her child the name 'Tea' or 'Minea'. You know, a name like 'Višnja' (cherry), 'Jagoda' (strawberry). A neutral name, you know? And then everyone knows immediately... I believe that this war had only one positive outcome: that we are no longer ashamed of ourselves!

Minela's narrative is full of ambivalence towards Yugoslavia. As we have seen, she speaks highly of Yugoslavia's progressiveness and the multinational coexistence it enabled and nurtured. She emphasises that people were all the same and that most people did not care about the nationality of their compatriots. She claims that only the Bosniaks have kept this spirit while the others in the Mostar context (referring primarily to Croats) have tried to distinguish themselves from the others. Despite this positive view of Yugoslavia and her values, Minela simultaneously argues that multinationality is dangerous when it affects personal spheres like marriage because it leads to loss of identity. When she says, 'I believe that this war had only one positive outcome: that we are no longer ashamed of ourselves'; she is referring to the strengthening of the Bosniak identity as a consequence of the war. We find both contrary discourses present in Minela's narrative - about the sameness of people and about a primordial national difference that one cannot and should not attempt to overcome.

On the one hand, we could reason that the ambivalences found in her narrative are connected to the ambivalent position Bosniak political elites hold (see Chap. 3). To a certain extent this may be true but I argue that this ambivalence is characteristic for the Last Yugoslavs regardless of their nationality. This will become clear with Željko, a Croat informant. As discussed earlier in the book, the present dominant Croat public discourse condemns Yugoslavia much more openly than the Bosniak one does. Željko's positive memories of Yugoslavia thus disturb the negative picture of Yugoslavia that he ideologically supports.

\section{Željko}

I met Željko through the so-called snowball effect. A friend of mine introduced me to one of her friends, who then introduced me to her uncle, Željko. I met Željko in his office in West Mostar where he works as 
a structural engineer. He was born in 1961 in a town that was then part of the Croat republic of the Socialist Federal Republic of Yugoslavia and today is a town in Croatia just at the border with $\mathrm{BiH}$. When he was 10 he moved to Mostar with his family, where he has remained until today. Only his wife and son spent part of the war in Germany. Before the war Željko enjoyed stable employment and worked for the same company for many years. Today his regular income is much too small to support his family and he has to do other work on the side. He has to support not only his nuclear family but also his mother, whose pension is too small to live on. This responsibility to support his family in the present difficult economic situation weighs heavily on his shoulders.

Like Minela, the war for Željko was a formative experience. Željko experienced the war first and foremost as soldier. He was mobilised by the HVO at the beginning of the war and served in the army until the ceasefire was achieved. The way Željko narrates the war is in stark opposition to Minela's narrative. In his narrative, the Croats are double victims, first of the Serbs and then of their former allies, the Bosniaks. While for Minela Herceg-Bosna represents a brutal regime that aimed to cleanse West Mostar of all non-Croats, for Željko the establishment of HercegBosna was an absolute necessity since in a state of chaos there was need for some kind of government. In his narrative, the aggression was initiated by the Muslims. He does not admit any guilt of the Croats but holds the Muslims fully responsible. He even justifies the notorious detention camp 'Heliodrom' with an anecdote about two HVO soldiers who were perfidiously killed by two Bosniak snipers. He feels that this incident was reason enough to take more drastic action.

I was surprised about Željko's openness about his experiences at HVO. A while into our conversation, I even had the feeling that Željko was relieved to tell me his story; so I asked him whether he had shared his war experiences with others before. As it turned out, he hardly had. He told me that he does not want to burden his family with these stories and that, if at all, he only speaks with other veterans about the war but then only to share funny anecdotes. All the veterans, Bosniaks and Croats alike, I talked to tend to keep their war experiences to themselves. They gave me different explanations for this decision, but most said they did not want to burden their loved ones. 
When Željko told me about his war experiences, his sentences were incomplete and often incoherent. This may be because he had not yet shared his war experiences with others, but it may also be because such experiences are difficult to share, especially with someone without a similar background. This is a small excerpt of what he narrated about his war experiences:

We all thought that this is something that will be over within three months. They [his parents, wife and young son] were at the sea in Makarska in this period, so that the child was safe. But whoever stayed here did not stay normal any longer. Do you understand what I mean? I went through the war, you know through bljesak and oluja [names of major military offensives] and so on. And then when I came home for some three months I was just not myself anymore. I think these were... although I was not in these... let's say, situations. Once or twice that I something... That means that, that... especially one of these units we faced. These people needed to be particularly courageous or crazy or on drugs. This is a category of people with which a state has to deal somehow, but the state does not exist. Do you understand? And then the war is over for you and I stayed here in a high-rise apartment building and this guy throws a bomb... throws a bomb from the balcony, he does not look who is down there. You know, that was the way things went. And I don't talk about shooting with, with... still the Serbs shot. We had to defend ourselves and they attacked.

And do you still think about it a lot?

Yes I do. Well, sometimes, sometimes... yes I do.

And with whom do you speak about it?

Sometimes with colleagues who went through the same things, this and that, some stories, but they are always, how to say, amusing events. These nicer things, not ugly things but, but nice things. There were a lot of, a lot of funny anecdotes, a lot of these tricks and so on. Not everything was so... you did not get killed every metre. Time has to pass. It is like that.

How much do you want to talk about this with your children?

Perhaps when they are older. Well, I don't talk about it with them. I don't talk about it a lot.

Do you think that they need to know...?

Well, they know that I was there. However, this period... this oluja the son remembers, but not really, it took place a long time ago. Well, this operation lasted... I don't know how well you are informed about it, I don't 
know from Herzegovina, from Livno and Glamoc, Grahovo, I don't know how well you know this terrain and this other side. I was not aware that I was in this military action (akcija) until I was out of it, you understand? I only know that I was there for 22 days. I was not aware that I was part of this military action until I turned on the radio the next day.

But about the war in general?

Generally with the kids, I don't talk about it. I don't talk about it. With the children-no. There is no need to. But I am always afraid when my little ones go to the left riverbank. Then I get a bit afraid.

In the excerpt cited above, Željko describes the war as a period of his life that took much longer than he expected, a period he was forced to go through and in which he became somewhat confused mentally. When talking about his war experiences, his language becomes vague and his sentences incomplete. Although I met an unexpected readiness in Željko to tell me about the war, at the same time it seemed he could not find the right words to do so. Das (2007: 90) describes this in the case of extreme violence experienced in India as the 'non-narrative'. Together with other authors (see, e.g., Argenti and Schramm 2010), Das argues that extreme violence has the potential to leave behind witnesses without words. Such experiences create disruptions in people's lives in the sense that they cannot relate them to the life they lived before. Moreover, the experienced violence is too far removed from 'normal life' for witnesses to share it with others.

The indescribability of their story is the fate veterans' face, not only in $\mathrm{BiH}$. Not only do they not want to burden others with their stories, but their experiences also seem impossible to share because they exceed what is regarded as normal experience (see Jackson 2006: 49). This results in a silence that manifests itself even between close family members, such as spouses, as I was told by several of my female interlocutors. Women who have re-joined their husbands after the war often had no information even about the positions their husbands held as soldiers. Some of the husbands showed clear signs of suffering from that time, for example nightmares, but the couples never talked about it. As Lomsky-Feder (2004) shows on the case of Israeli veterans, the male fighter is expected to return after the battle to 'business as usual', to return home not showing any effects of the war or only at night when nobody notices. 
In the last part of the excerpt, Željko states that he does not want to share his war experiences with his children. As will be discussed in the analysis of the Post-Yugoslav generation, the silence regarding the war, particularly by older (male) family members about their war experiences, irritates the younger ones. Even if Željko does not speak with his children about the war, he conveys to them that the 'others' are still the Croats' enemies and one cannot be careful enough. In the last sentence Željko unexpectedly and directly shares, 'But I am always afraid when my little ones go to the left riverbank'. Željko himself had cut all relationships to Bosniaks aside from professional ones. When I asked him whether he sometimes went to the east side of the city, he answered:

I have no desire to go to theirs [Bosniak side].

Where?

Down there to the Old Bridge.

You don't go there?

No I don't. I have not been there for I think a year, definitely.

But before the war you went there, right?

Before the war, we spent much time down there. When I was a student I was there all the time.

And now you don't feel like it?

I don't have any desire whatsoever, whatsoever!

Why?

I think because of the way the Muslims behave, with this particular relation to, well, let's say, Islam.

[...]

And your Bosniak friends [the ones he earlier mentioned to me] are they different then, are they not like that?

We try to avoid such conversations like the two of us are engaged in now. That means we talk about other things, primarily about work related things. [...] You know, when my mobile phone rings a Croat song plays, the one from the recent Eurovision [song contest]. If I went down there I would have to turn it off, you know, so that nobody attacks me at the bar... do you know what I mean?

As becomes evident in the excerpt above, Željko has made a clear decision not to cross sides. His relationships with Bosniaks are restricted to his work. 
He also strongly wishes that his children do not cross to the Bosniak side, which he justifies with the potential danger that such a crossing implies. In order to strengthen his argument, Željko reminds me about the young Australian man who had been beaten up in East Mostar a few weeks earlier because he wore a Croat football jersey. Although my interlocutors were aware that violent attacks had become rare, they were taken as good reasons why one (or one's children) should not cross sides.

In Željko's view, the future for Croats in Mostar looks grim. He believes that the Muslims want to take over the city and that gradually the Croat population will have to emigrate. Željko claims that Mostar was a Croat city before the war but that this is not the case anymore today. This view is interesting if we consider that Croat population in Mostar has steadily grown since the war and that it is most likely that Croats even hold majority status now, while Bosniaks had been the strongest nation before the war (see Chap. 2). Nonetheless, Željko compares the situation in Mostar with the situation in Kosovo, where the Albanian population became the great majority within a few decades and the Serbs remained only as a very small minority. For him, Muslims are not neighbours anymore, because neighbours know what belongs to them and what does not; as Željko argues:

We [Croats] know how to communicate with neighbours here in Herzegovina. Because neighbours know what is theirs and I know what is mine. And that is why it works out so well. But if you don't know what belongs to whom then nothing works anymore. And I think in the relation between Croats and Muslims, Muslims think that everything is theirs and they don't know what is theirs. And that is why I am for a third entity!

Here Željko does not contrast the bad neighbourliness (loš komšiluk) with the intact one before the war, as is commonly done, but he instead contrasts the Bosniak understanding of komsiluk with that of Croats', identifying the former as inferior. This presents a decisive shift in argumentation, since the art of komsiluk in this discourse belongs solely to one nation and not to all, as is usually the case in nostalgic discourse on pre-war Mostar. Željko clearly positions himself against future coexistence and is convinced that $90 \%$ of the Croat population shares his opinion and would opt for a third entity, a Croat entity. In his view, as 
in the view of the Croat historian introduced in Chap. 3, this is the only viable option for Croats to survive in $\mathrm{BiH}$.

One of the examples Željko gave for his evaluation of Bosniak nonneighbourly behaviour concerns the controversy about the Croat member of the $\mathrm{BiH}$ presidency. The presidency is supposed to be shared among Bosniaks, Croats and Serbs, whereby three presidents govern in rotation. In the 2006 general election, Željko Komšić was the SDP's candidate for the Croat seat in the presidency member, which he won. It was the first time since the war ended that the Croat presidency was not a member of the HDZ. Komšić's success can be traced to two main factors: the then recent split of the Croat national party $\mathrm{HDZ} \mathrm{BiH}$ into two factions, and the strong support he received from Bosniak voters. Komšić is not perceived to be a proper Croat because, although from a Roman Catholic family, he himself is an agnostic. Moreover, he does not hold dual citizenship ( $\mathrm{BiH}$ and Croat) as many other Croats in $\mathrm{BiH}$. He also propagates a shared $\mathrm{BiH}$ and is married to a Bosniak. For Željko, as for many other Croats, these are plenty of reasons why Komšić is not a suitable Croat representative in the presidency. But this was exactly why so many Bosniaks cheered upon his victory. I remember seeing many bright faces among my Bosniak friends and hearing cynical comments about the results of the election. Ultimately, this situation underscores the absurdity of the Dayton Peace Agreement and the governmental structure it produced. But for Željko it was proof of Bosniaks' non-neighbourly behaviour and their attempt to take away what belongs to the Croat nation.

So far, the way Željko represents the situation of Croats during and after the war is very much in line with the current dominant public discourse espoused by the Croat political elites. When he talks about pre-war Mostar, however, his narrative deviates. He acknowledges Tito's achievement in playing an intermediary role between the Soviet bloc and the West. Moreover, he fondly remembers that people had jobs and good incomes, generally enjoyed a good life and that everyone including his parents were extremely sad upon Tito's death. Željko further recalls that when he was in school everyone, regardless of national background, got along well and he is still friends with his former school friends. However, it soon becomes clear that most of these friends have left the city and he has lost contact with them. His statement about still being friends with 
his former school friends of other nationalities may rather mean that Željko does not see them as enemies because he was never 'forced' to classify them along a friend-enemy framework.

Indeed, Bosniaks and Serbs from pre-wartime were friends and may remain friends (in Željko's memory) because they left Mostar, but Bosniaks (and Serbs) whom Željko meets today cannot become friends anymore because this would dangerously blur the boundary between Bosniaks and Croats, thereby threatening Croat existence. This fear of the Croat nations' assimilation and absorption is clearly in line with the dominant Croat public discourse. Nevertheless, as opposed to the Croat professor introduced in Chap. 3, who is professionally involved in rewriting history and denies any positive experiences of Yugoslavia, Željko's narrative includes positive personal memories of Yugoslav times. At several points during our interview Željko came to realise the discrepancies between the dominant Croat discourse he follows when narrating the present situation and the divergent discourse when narrating his personal experiences of pre-wartime. The explanation he gave for it, however, rested on the argument that he was simply ignorant during the period of Yugoslavia. He claimed he was not politically sensitive enough to realise his nation was being repressed (including the economic injustices of, for example, Western Herzegovina, a region dominated by Croats). He blames his ignorance on his age, stating he was too young and more interested in playing football than engaging in serious subjects.

Not only on the subject of national coexistence but also his position towards the church and ongoing present language politics demonstrate how Željko is caught between different discourses. Although he ideologically supports Croat national politics, from time to time he reverts to interpretative templates from Yugoslav times. In terms of language, Željko says how amusing it is that his children do not understand some of the words he uses, words that are today regarded as Serb and have been replaced by 'proper Croat' words. From what he told me, I initially concluded that his children are exposed to this revised language in school while he himself is unwilling to change his language, but I learned otherwise:

No, no, no when we were in school we were taught in what was called Serbo-Croatian and it was predominantly Serb. The Muslims took over a 
lot of Serbian. Well, they made some sort of Bosniak language [sic: not Bosnian!]. They made a language and then they unmade it again. There are a lot of these things going on. Well, but I did not know about it. What does a child know? Is it Serbian, is it Croatian kava or kafa [both meaning coffee but the first is used today primarily by Croats while the latter is used by Bosniaks and Serbs] and so forth.

What do you use now? Hljeb or kruh? [Both meaning 'bread' but the first is used today primarily by Bosniaks and Serbs and the latter by Croats.]

Now kruh. Now I use the Croatian word.

Was hljeb more in use or both before the war?

Before it was hljeb.

As becomes evident in the cited excerpt, Željko actually expresses sympathy for this linguistic development, even if he finds some situations resulting from it bewildering. He claims, however, that he used these words only because he was unaware they were actually of Serb origin. Now that he knows better, he has adapted his language. This attitude is different for the First Yugoslavs I introduced in the previous chapter, who are more reluctant to change their language.

Later during the same conversation, I asked Željko about his relationship with the church:

\section{And how is your relationship to the church?}

To the church? I don't... my father... the relation of my family always has been... my father's not my mother's! My mother always went to church and so forth, but my father was a communist. And so was I. I just did not go to church.

And your children?

The children are... I don't know. You know what? Still, how can I say, religious education. You know, that is for me... I have always been against it. Who wants to join religious education should go, that's fine, but not in school, not to misuse it. Do you understand? Of all these subjects. And they have many of them. They have one year of computer science and four of religious education, right? I think it would be better to invest in another language. I am really against it... I have always had a good relationship with the church. [...] Well, but I think it goes too far, too far into our lives. [...] I would say, wait until the children are 18 and then they should choose 
for themselves. For some time during the war you could not earn a domovnica ${ }^{4}$ from Croatia if you were not baptised [in the Catholic Church]. You know, that is discrimination.

It is obviously not easy for Željko to express his (and his family's) relationship with the church. He constantly searches for the right words but does not seem to find them. The way he positions himself vis-à-vis the church is very vague. It is possible that he has not been asked about this issue in such an explicit manner before. While he talked it seemed as if he suddenly became aware of his out-dated views stemming from Yugoslav times. He and his father were both in the Communist Party and his father distanced himself strongly from the church, although his wife attended church. During our conversation, Željko probably became aware that his criticism of the church and its involvement in education and politics is not 'politically correct' anymore, and he eventually softened his criticism towards the church when he talked about his daughter's involvement in it. In this case he believes that his daughter is in good hands and that the values the church teaches are the right ones.

The narratives of Minela and Željko show that the Last Yugoslavs are the generation who struggles most in the process of (re-)positioning themselves towards their own and their nation's past and at the same time of (re-)envisioning the future. In this reorientation process, two central phenomena can be observed: firstly, the narratives of the Last Yugoslavs tend to oscillate between different, even opposing, discourses; and secondly, narratives do not proceed towards a conclusion but show a lack of cohesiveness.

The rupture that the war and the end of socialist Yugoslavia caused in the lives of the Last Yugoslavs not only finds expression in the three-fold time frame discussed above, but also penetrates their narratives as a whole, creating accounts that are characterised by a lack of conclusiveness. This is different for the older and younger generations, whose narratives are much more conclusive. While the First Yugoslavs tend to connect the two wars they experienced during their lifetime into a broader and more coherent narrative, the Post-Yugoslavs tend to distance themselves from wider

\footnotetext{
${ }^{4}$ The domovnica is an official document providing proof of Croat origin.
} 
societal experiences caused by the war. The Last Yugoslavs' narratives of local history and of their lives as being closely bound to it stand out due to the way they oscillate between different discourses: one localised discourse centring around the worsening of quality of life with the break-up of Yugoslavia and the war, and one delocalised discourse centring around the national liberation that came with it. While the former constitutes an immediate experience, the latter exists on a more ideological level.

\section{Lost Homes: Oscillating Between Opposing Discourses}

As has been shown, the narratives of the Last Yugoslavs are characterised by two central phenomena. First, they tend to oscillate between different, even opposing, discourses. Second, they are subject to the disruption that the war and the political-economic transformations caused. This disruption in the expected life course (in regard to education and career as well as family life) continues to this day, since for many of this generation life and, in particular, the course of their life remains 'out of order'. In the Last Yugoslavs' narratives, pre-war $\mathrm{BiH}$ is presented as the 'secure past', while present and future $\mathrm{BiH}$ is seen as insecure, even for those who are in favour of Mostar's division and support the nationalist discourse.

Besides human losses and loss of familiar neighbourhoods, the loss of economic security (viewed with reference to the extremely precarious economic situation many people face today $)^{5}$ has had a strong impact on the lives of the Last Yugoslavs. Severe changes brought about by the war, as well as by the transformation of the Yugoslav socialist market economy into a neoliberal, capitalist-oriented economy, directly affected the lives of the Last Yugoslavs. Thus we can say this generation experienced a 'double rupture' (Jansen 2008: 47).

This generation's discursive tactics are marked by their attempts to deal with their ruptured biographies. Compared to the First Yugoslavs, the narratives of the Last Yugoslavs show much less continuity and conclusiveness. While the First Yugoslavs are likely to connect the recent war and

\footnotetext{
${ }^{5}$ In 2008 the average income in $\mathrm{BiH}$ was around 400 Euros; around $40 \%$ of the population described their household situation as below average (see UNDP 2008/3).
} 
their experience of it with WWII or to embed it in a narrative of suffering that goes beyond the experience of war, in the narratives of the Last Yugoslavs the 1992-1995 war stands out as an experience that cannot be connected to any other experience. Moreover, a longing is expressed for the normal life (normalan život), which is tightly connected to the social security and economic well-being people fondly remember from Yugoslav times but also to good komšiluk (neighbourliness) (see Jansen 2015; Spasić 2012). So, we may say that the idea of normalan život and its connotations are an interpretative template borrowed from Yugoslav times.

In this nostalgic discourse Yugoslavia is often remembered as the ideal home, a lost home that can never be regained (Palmberger 2008). Home thus does not represent a geographically defined place but is, as Jansen (2007) vividly shows in the case of BiH's returnees, strongly tied to feelings of security (Sicherheit), which again is bound to specific needs arising from the stage of life in which people find themselves. For the Last Yugoslavs, pre-war, not post-war, Mostar presents this 'secure' place. Evidently, only the relatively prosperous Yugoslav period is remembered by the Last Yugoslavs and not the economic decay of the 1980s. Even if social security and equality were central ideals of Tito's Yugoslavia in order to legitimise the socialist regime, these ideals were never achieved and the system failed to develop progressive redistributive mechanisms. Basic social securities, for example, in respect to housing, health care and education —often mentioned by my informants-were not as abundant as they are remembered today (see Allcock 2000; see also Pešić 1988). ${ }^{6}$ Nevertheless, in the narratives of the Last Yugoslavs the past is clearly set in relation to the present. Considering the extreme difficult economic situation BiH's citizens face today, Yugoslavia is recalled in a highly idealised fashion and evidently only the relatively prosperous period is remembered and not the economic crisis of the 1980s.

In the case of Aida and her longing for Yugoslavia it became clear that a loss of home can be experienced even when one is, geographically speak-

\footnotetext{
${ }^{6}$ Especially in urban areas accommodation was in chronic short supply and, with a few exceptions, only those in leadership positions received housing through their occupational position. In terms of healthcare it has to be said that it was free but medicine provision was not. Education was free, too, but there was limited financial aid available. Moreover, unemployment insurance was not sufficient (Allcock 2000: 192-194).
} 
ing, at home. Although after the war she returned to Mostar, the city she grew up in, Aida continues to experience a deep loss of home. Jansen and Löfving (2009) rightly remind us that it is wrong to assume that home is where one grew up or is a geographically defined place as:

Home itself, then, needs to be problematised, and particularly the selfevidence with which it is territorialised. If we fail to do so [...], home is all too easily represented unwittingly as a timeless entity in an unchanging context of origin, something that is particularly inappropriate if we take into account that that context is often one of dramatic transformation, such as war or socioeconomic restructuring. There is, then, an important temporal dimension to experiences of home. (Jansen and Löfving 2009: 15)

With the above point in mind, we can better understand why those who decided to resettle in Mostar (and even those who never left the city) experienced a loss of home in the sense that they lost the city they felt at home in. Some even said they do not regain a sense of familiarity when re-visiting places, although they previously had lived there for more than half their lifetime. ${ }^{7}$ Returning 'home' (or remaining at 'home') actually meant building a new life in a place that has suffered severe transformations. Although this chapter focused on those who remained in or returned to Mostar, it has to be said that this generation was particularly reluctant to return to their pre-war homes, at least on a permanent basis (see Jansen 2009).

The notion of home, we can say, is closely connected to people's sense of socio-economic security and future prospects that abruptly vanished with the war. Life presents itself as fractured and there is a dramatic discontinuity between life before the war and life after the war. This is a phenomenon observed in cases of abrupt and traumatising life changes, particularly researched in the cases of Holocaust survivors (see Rosenthal 1995). As discussed in this chapter, home cannot be defined as a geographical place but is connected to familiar social relationships and physical and economic securities and provides room for dreams of and

\footnotetext{
${ }^{7}$ Returning 'home' but not recognising that place as home any more is a common experience among Bosnian returnees (see Jansen 2006; Stefansson 2006).
} 
aspirations for the future. This loss of home, I argue, is a crucial reason for the lack of conclusiveness in the narratives of the Last Yugoslavs generation. In contrast to those of my informants who taught local history in school or university, my informants presented here could not rewrite local history by erasing their personal memories. They did not fully adapt their own memories to accommodate the dominant national discourses but rather shifted between different discourses-old and new.

Although the loss of home was discussed most explicitly in Aida's case, it is a consistent theme running through all of the narratives presented. Moreover, a sense of loss of home is not unique to the Last Yugoslavs but is also a strong element in the narratives of the First Yugoslavs, as discussed in the previous chapter. Still, for the Last Yugoslavs, the rupture of the war came at a critical point in life when they were establishing their own households and building up their careers or when they were just about to do so. Aida blames the war for foiling her life plans (especially in terms of career and family) and for the fact that she still lives at home with her parents at a point in her life when she expected to be setting up her own household.

Becker (1997), in her book Disrupted Lives, draws a clear parallel between expectations about the course of life that do not materialise because of unexpected life events and the experience of biographical disruption. Becker conducted research with Americans whose lives took an unexpected turn because of diverse reasons, including infertility as well as chronic illnesses. Becker noticed that her informants share the experience of disruption of a life course pictured as a predictable continuous flow. 'Although continuity in life is an illusion, it is an effective one: it organizes people's plans for and expectations about life, as well as the ways in which they understand who they are and what they do' (Becker 1997: 191). Becker's observations, as well as my own, suggest that ideas of the future are closely connected to the life course. When the flow of life is interrupted due to unexpected circumstances, the anticipated future disintegrates and a coherent narrative that connects past-present-future is under threat. As I realised in the case of the Last Yugoslavs' narratives, when expectations concerning one's life course are hampered by wide-reaching societal transformations and war, it is not only one's physical integrity that is threatened, but also the meaningful life that people long for. This makes 
clear that we need to consider questions concerning the life course in order to understand the multiple ways people position themselves toward and make sense of historical-political ruptures.

The life situation the First Yugoslavs face (presented in the previous chapter) gives them more leeway where they are not forced to grapple with the political and economic changes the way the Last Yugoslavs have to. The former also seem to find more possibility and legitimacy in indulging in the past and to remain among like-minded people in order to revive the spirit of the 'good old days' and to cherish a generationally shared past time. The Last Yugoslavs face the difficult task of orienting themselves anew in a society that has changed so significantly. Those who feel incapable of doing so experience the world around them as alien and often also hostile. Oftentimes, the place where they were born is not experienced as home anymore and the experience of loss of home is shared not only by those who left the country but also by those who remained in or returned to Mostar.

While there seems to be a consensus in the literature that individuals aim to 'connect disparate parts into a coherent, meaningful whole' (Holstein and Gubrium 1995: 28; see also Roseman 1995), in this chapter I have shown that this is not necessarily always possible. In the case of the generation of the Last Yugoslavs I argued that the experience of disruption and loss of future prospects due to the dissolution of Yugoslavia, the war and political-economic transformations prevent people from narrating their lives and the history of their society in meaningful and coherent ways. Moreover, I have revealed that the way wider societal transformations in Mostar are perceived as biographical disruptions varies along generational (rather than national) lines.

I have, moreover, shown that generational demarcations are informed by the past as well as by present shared experiences and by expectations of the future (or lack thereof), which are closely connected to the life course. Due to the life situation the Last Yugoslavs find themselves in, they face a particular challenge when it comes to re-orienting themselves in the new post-war socio-political context. The Last Yugoslavs' narratives discussed above have illustrated how the disappearance of a home and the future prospects tightly tied to it hamper the construction of a coherent and meaningful narrative. As some researchers working with refugees have 
observed, a sense of belonging and of home is crucial for a coherent narrative of one's life: 'Forced movement as a rupture with the familiar social world tends to undermine the premises on which meaningful stories are built' (Eastmond 2007: 259). Although not all Mostarians experienced forced movement, they all experienced the disappearance of a familiar world. As long as they have not found a new home that suffices as a base from which to create future projections, they are likely to struggle to find a coherent life narrative. As Skultans (1997) has shown in her vivid account of Latvian life narratives, her interlocutors were able to deal well with loss and discontinuities as long as they found 'an end' to the stories of their lives. For Skultan's Latvian interlocutors, the end of their story is the homecoming. However, as has been shown above, no such homecoming exists for the majority of my interlocutors who belong to the generation of the Last Yugoslavs. Moreover, even for those who believe that the war has fostered national liberation, it seems too abstract an achievement to serve as the 'story's end'.

\section{Bibliography}

Allcock, John B. 2000. Explaining Yugoslavia. New York: Columbia University Press.

Andrić, Iris, et al. 2004. Leksikon Yu Mitologije. Belgrade: Rende.

Argenti, Nicolas, and Katharina Schramm. 2010. Remembering Violence: Anthropological Perspectives on Intergenerational Transmission. New York: Berghahn.

Basic-Hrvatin, Sandra. 1996. Television and National/Public Memory. In Bosnia by Television, eds. J. Gow, R. Paterson, A. Preston, and British Film Institute, 63-71. London: British Film Institute.

Becker, Gay. 1997. Disrupted Lives: How People Create Meaning in a Chaotic World. Berkely: University of California Press.

Bertaux, Daniel, and Paul R. Thompson. 2009. Introduction. In Between Generations: Family Models, Myths, and Memories, eds. D. Bertaux and P. R. Thompson, 1-12. Oxford: Oxford University Press.

Boym, Svetlana. 2001. The Future of Nostalgia. New York: Basic Books.

Das, Veena. 2007. Life and Words: Violence and the Descent into the Ordinary. Berkeley: University of California Press. 
Davis, Fred. 1977. Nostalgia, Identity and the Current Nostalgia Wave. Journal of Popular Culture 11(2): 414-424.

—_. 1979. Yearning for Yesterday: A Sociology of Nostalgia. New York: Free Press.

Duijzings, Ger. 2007. Commemorating Srebrenica: Histories of Violence and the Politics of Memory in Eastern Bosnia. In The New Bosnian Mosaic: Identities Memories and Moral Claims in a Post-War Society, eds. X. Bougarel, E. Helms, and G. Duijzings, 141-166. Aldershot: Ashgate.

Eastmond, Marita. 2007. Stories as Lived Experience: Narratives in Forced Migration Research. Journal of Refugee Studies 20(2): 248-264.

Hann, Chris, Caroline Humphrey, and Katherine Verdery. 2002. Introduction: Postsocialism as a Topic of Anthropological Investigation. In Postsocialism: Ideals, Ideologies and Practices in Eurasia, ed. C.M. Hann, 1-28. London: Routledge.

Hayden, Robert. 1994. Recounting the Dead. The Rediscovery and Redefinition of Wartime Massacres in Late- and Post-Communist Yugoslavia. In Memory, History, and Opposition under State Socialism, ed. R. Watson, 167-189. Santa Fe, NM: School of American Research Press.

Holstein, James A., and Jaber F. Gubrium. 1995. The Active Interview, Sage University Paper. Thousand Oaks, CA: London: Sage.

Jackson, Michael. 2006. The Politics of Storytelling: Violence, Transgression, and Intersubjectivity, Critical Anthropology. Copenhagen: Museum Tusculanum Press.

Jansen, Stef. 2006. The Privatisation of Home and Hope: Reform and the Foreign Intervention in Bosnia-Herzegovina. Dialectical Anthropology 30(3-4): 177-199.

of 'Home' in Bosnia-Herzegovina. Focaal-European Journal of Anthropology 49: $15-30$.

- 2008. "Home" and Return in the Foreign Intervention in Bosnia and Herzegovina: An Anthropological Critique. In Deconstructing the Reconstruction. Human Rights and the Rule of Law in Postwar Bosnia and Herzegovina, ed. D.F. Haynes, 29-51. Aldershot: Ashgate.

. 2009. Troubled Locations: Return, the Life Course and Transformations of Home in Bosnia-Herzegovina. In Struggles for Home: Violence, Hope and the Movement of People, eds. S. Jansen and S. Löfving, 43-64. New York: Berghahn Books.

- 2015. Yearnings in the Meantime: 'Normal Lives' and the State in a Sarajevo Apartment Complex. New York: Berghahn. 
Jansen, Stef, and Staffan Löfving. 2009. Introduction: Towards an Anthropology of Violence, Hope and the Movement of People. In Struggles for Home: Violence, Hope and the Movement of People, eds. S. Jansen and S. Löfving, 1-24. New York: Berghahn Books.

Lomsky-Feder, Edna. 2004. Life Stories, War, and Veterans: On the Social Distribution of Memories. Ethos 32(1): 82-109.

Moll, Nicolas. 2013. Fragmented Memories in a Fragmented Country: Memory Competition and Political Identity-Building in Today's Bosnia and Herzegovina. Nationalities Papers 41(6): 910-935.

Müller, Jan-Werner, ed. 2002. Memory and Power in Post-War Europe. Studies in the Presence of the Past. Cambridge: Cambridge University Press.

Palmberger, Monika. 2008. Nostalgia Matters: Nostalgia for Yugoslavia as Potential Vision for a Better Future? Sociologija. Casopis za sociologiju, Socijalnu Psihologiju i Socijalnu Antropologiju 50(4): 355-370.

- 2013. Acts of Border Crossing in Post-War Bosnia and Herzegovina: The Case of Mostar. Identities: Global Studies in Culture and Power 20(5): 544-560.

Papić, Žarko. 2001. Policies of International Support to Southeast European Countries: Lessons (Not) Learnt in Bosnia-Herzegovina. Sarajevo: Open Society Institute. http://test.soros.org.ba/docs/eng_politike_medunarodne_podrske_ zemljama_jugoistocne_evrope.pdf [20.10.2015].

Pešić, Vesna. 1988. Kratki Kurs o Jednakosti: Koncepcija Jednakosti u Zvaničnoj Ideologiji Jugoslovenskog Društva. Beograd: Sociološko društvo Srbije.

Pickering, Michael, and Emily Keightley. 2006. The Modalities of Nostalgia. Current Anthropology 54: 919-941.

Pugh, Michael. 2005. Transformation in the Political Economy of Bosnia since Dayton. International Peacekeeping 12(3): 448-462.

Radstone, Susannah. 2010. Nostalgia: Home-Comings and Departures. Memory Studies 3(3): 187-191.

Roseman, Mark. 1995. Generations in Conflict: Youth Revolt and Generation Formation in Germany 1770-1968. Cambridge: Cambridge University Press.

Rosenthal, Gabriele. 1995. Erlebte und erzählte Lebensgeschichte: Gestalt und Struktur biographischer Selbstbeschreibungen. Frankfurt/Main: Campus.

Skultans, Vieda. 1997. Theorizing Latvian Lives: The Quest for Identity. The Journal of the Royal Anthropological Institute 3(4): 761-780.

Spasić, Ivana. 2012. Yugoslavia as a Place for Living a Normal Life: Memories of Ordinary People in Serbia. Jugoslavija kao Mesto Normalnog Života: Sećanja Običnih Ljudi u Srbiji 54(4): 577-594. 
Stefansson, Anders. 2006. Homes in the Making: Property Restitution, Refugee Return, and Senses of Belonging in a Post-War Bosnian Town. International Migration 44(3): 115-139.

Sutton, David. 2001. Remembrance of Repasts: An Anthropology of Food and Memory, Materializing Culture. Oxford: Berg.

Tannock, Stuart. 1995. Nostalgia Critique. Cultural Studies 9(3): 453-464. Ugrešić, Dubravka. 2006. The Ministry of Pain. New York: Harper Collins. UNDP. 2008/3. Early Warning System Quarterly Report. Sarajevo: UNDP.

Volcic, Zala. 2007. Scenes from the Last Yugoslav Generation: The Long March from Yugo-Utopia to Nationalisms. Cultural Dynamics 19(1): 67-89. Young, Allan. 1995. The Harmony of Illusions: Inventing Post-Traumatic Stress Disorder. Princeton, NJ: Princeton University Press.

Open Access This chapter is distributed under the terms of the Creative Commons Attribution 4.0 International License (http://creativecommons.org/licenses/by/4.0/), which permits use, duplication, adaptation, distribution, and reproduction in any medium or format, as long as you give appropriate credit to the original author(s) and the source, a link is provided to the Creative Commons license, and any changes made are indicated.

The images or other third party material in this chapter are included in the work's Creative Commons license, unless indicated otherwise in the credit line; if such material is not included in the work's Creative Commons license and the respective action is not permitted by statutory regulation, users will need to obtain permission from the license holder to duplicate, adapt or reproduce the material.

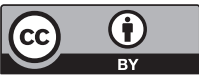

